\section{$\mathrm{Y}-12$}

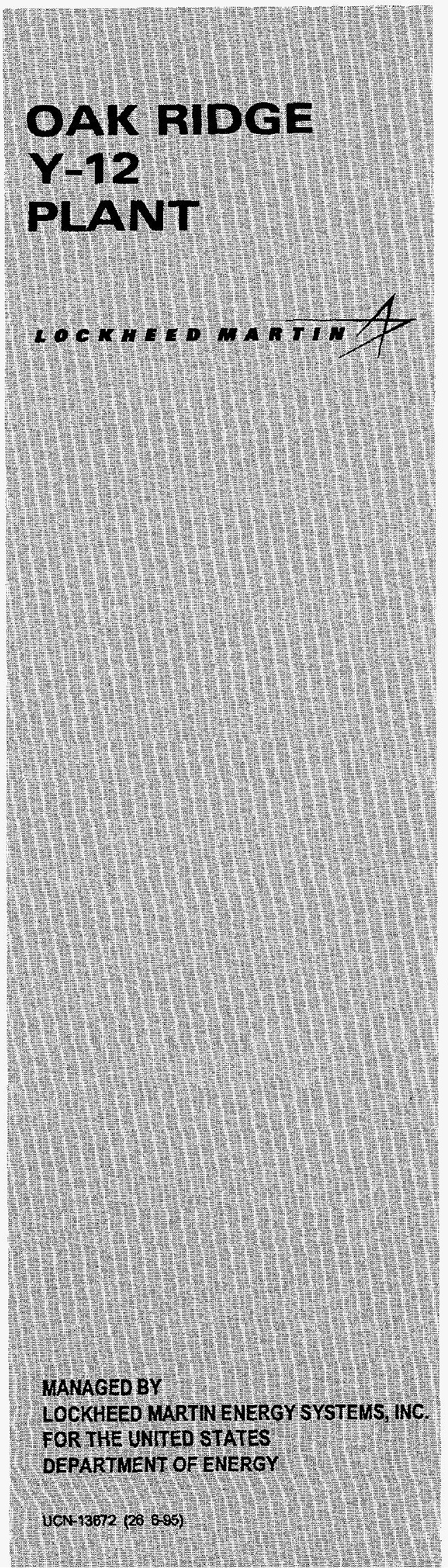

\section{ASSESSMENT OF FLOOD POTENTIAL FOR EIGHT BUILDINGS AT THE Y-12 PLANT}

\author{
Prepared by \\ P-Squared Technologies, Inc \\ for \\ Oak Ridge Y-12 Plant
}

Oak Ridge, Tennessee 37831-8169

\section{MASTER}

December 12, 1997

Operated by

LOCKHEED MARTIN ENERGY SYSTEMS, INC for the

U. S. Department of Energy

under Contract No. DE-AC05-840R21400

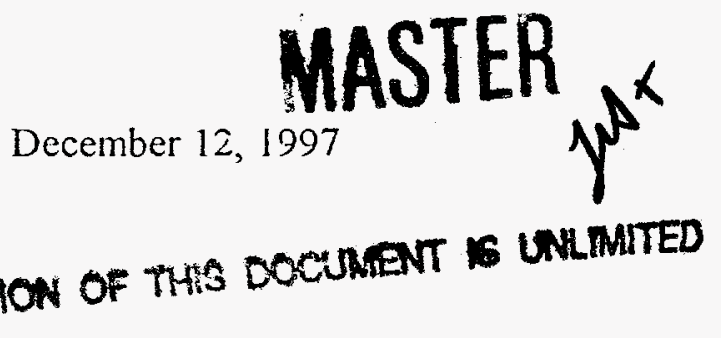




\section{DISCLAIMER}

Portions of this document may be illegible electronic image products. Images are produced from the best available original document. 


\title{
ASSESSMENT OF FLOOD POTENTIAL FOR EIGHT BUILDINGS AT THE Y-12 PLANT
}

Michael A. Eiffe, P.E.

\author{
Prepared by \\ P-Squared Technologies, Inc. \\ P. O. Box 22668 \\ Knoxville, TN 37933
}

for

Oak Ridge Y-12 Plant

Oak Ridge, Tennesee 37831-8169

\author{
Operated by \\ LOCKHEED MARTIN ENERGY SYSTEMS, INC. \\ for the \\ U. S. Department of Energy \\ under Contract No. DE-AC05-840R21400
}

December 12, 1997 


\section{CONTENTS}

FIGURES $\ldots \ldots \ldots \ldots \ldots \ldots \ldots \ldots \ldots \ldots \ldots \ldots \ldots \ldots \ldots \ldots \ldots \ldots \ldots$

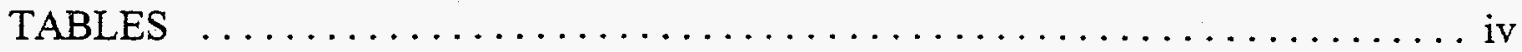

ABBREVIATIONS AND ACRONYMS $\ldots \ldots \ldots \ldots \ldots \ldots \ldots \ldots \ldots \ldots$

EXECUTIVE SUMMARY $\ldots \ldots \ldots \ldots \ldots \ldots \ldots \ldots \ldots \ldots \ldots \ldots \ldots \ldots$

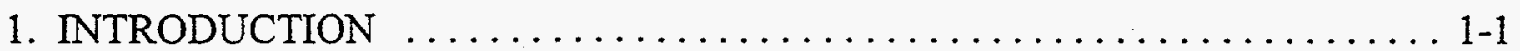

2. PREVIOUS WORK AT Y-12 PLANT $\ldots \ldots \ldots \ldots \ldots \ldots \ldots \ldots \ldots \ldots \ldots \ldots$

3. ANALYSES OF EXPECTED FLOODING CONDITIONS $\ldots \ldots \ldots \ldots \ldots \ldots$ 3-1

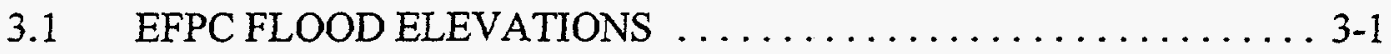

3.2 FLOOD ELEVATIONS WITHIN Y-12 PLANT AREA . . . . . . . . 3-1

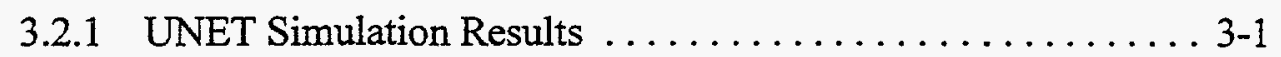

3.2.2 HEC-RAS Simulation Results . . . . . . . . . . . 3-3

4. SUMMARY OF FLOOD POTENTIAL $\ldots \ldots \ldots \ldots \ldots \ldots \ldots \ldots \ldots \ldots$. $\ldots \ldots \ldots$

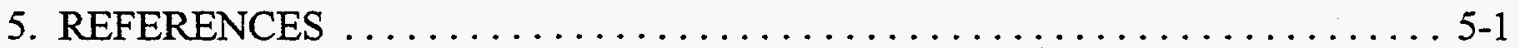




\section{FIGURES}

Fig. 1.1. General location map of study area within the $\mathrm{Y}-12$ Plant $\ldots \ldots \ldots \ldots 1-2$

Fig. 3.1. EFPC water surface profiles computed with P2T HEC-2 model . . . . . . 3-2

Fig. 3.2. Location of UNET reaches 1 through $13 \ldots \ldots \ldots \ldots \ldots \ldots \ldots \ldots$

Fig. 3.3. Maximum water surface profiles for UNET Reach $3 \ldots \ldots \ldots \ldots \ldots$ 3-5

Fig. 3.4. Maximum water surface profiles for UNET Reach $5 \ldots \ldots \ldots \ldots \ldots$ 3-6

Fig. 3.5. Maximum water surface profiles for UNET Reach $6 \ldots \ldots \ldots \ldots \ldots$. . . . . .

Fig. 3.6. Maximum water surface profiles for UNET Reach $9 \ldots \ldots \ldots \ldots \ldots$ 3-8

Fig. 3.7. Maximum water surface profiles for UNET Reach $10 \ldots \ldots \ldots \ldots \ldots$. . . . . . . . . . . . .

Fig. 3.8. Maximum water surface profiles for UNET Reach $11 \ldots \ldots \ldots \ldots \ldots$ 3-10

Fig. 3.9. Maximum water surface profiles for UNET Reach $12 \ldots \ldots \ldots \ldots \ldots$ 3-11

Fig. 3.10. Building $9720-38$ location map . . . . . . . . . . . . . . . 3-12

Fig. 3.11. Water surface profiles from HEC-RAS simulations $\ldots \ldots \ldots \ldots \ldots \ldots$ 3-13

\section{TABLES}

Table 2.1. Rainfall depth in inches for varying durations and frequencies

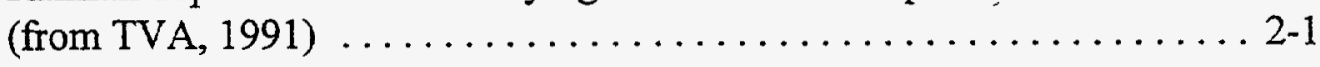




\section{ABBREVIATIONS AND ACRONYMS}

DOE Department of Energy

EFPC East Fork Poplar Creek

ORR Oak Ridge Reservation

P2T P-SQUARED Technologies, Inc.

TVA Tennessee Valley Authority 


\section{EXECUTIVE SUMMARY}

In 1995, P-SQUARED Technologies, Inc., (P2T) was tasked with defining the flood potential for seven buildings at the Y-12 Plant (Buildings 9204-2, 9204-2E, 9206, 9212, $9215,9720-5$, and 9995) in the assumed event of a design storm with a recurrence interval of 10,000 years. At the conclusion of the study, P2T prepared and submitted a report summarizing the flood potential for those seven buildings (P2T, 1995). The 1995 study was performed to satisfy a portion of the requirements included in the United States Department of Energy (DOE) Standard 1020, entitled "Natural Phenomena Hazards Design and Evaluation Criteria for Department of Energy Facilities" (DOE, 1994).

In November of 1997, P2T was tasked with 1) defining flood potential for the same seven buildings listed above for design storms with recurrence intervals of 500 years and 2000 years, and 2) defining flood potential for Building 9720-38 for design storms with recurrence intervals of 500 years, 2000 years, and 10,000 years. This report presents the results of the analyses conducted to define flood potential at these locations and for these recurrence intervals.

For the first task, the approach and methodology developed in the 1995 study was essentially repeated here. For the second task, P2T developed a separate approach which is described in the body of this report. All analyses were based on the assumption that storm runoff associated with the large rainfall depths investigated would surcharge the existing storm drainage system. Flood potential throughout most of the Y-12 Plant in these events is therefore defined by large volumes of storm runoff draining toward East Fork Poplar Creek (EFPC) through the streets between the buildings of the Plant.

Standard hydrologic techniques were used to generate discharge hydrographs and to compute peak rates of runoff for the design storms. Peak water surface elevations were computed using various models including UNET, HEC-2, and HEC-RAS. Modeling results show flooding depths will range from less than $1 \mathrm{ft}$ (at Buildings 9212 and 9995) to about $8 \mathrm{ft}$ (on the west side of Building 9204-2E for the 2000-year flood event). Computed flooding depths at most locations of interest vary between 1 and $3 \mathrm{ft}$.

Building 9720-5 is subject to flooding primarily from EFPC backwater. The other seven buildings (including Building 9720-38, investigated for the first time in the current study) are subject to flooding primarily from surface runoff draining through the $Y-12$ Plant area towards EFPC.

None of the buildings investigated are completely safe from flooding during the storms considered. Runoff from rooftops may cause limited flooding in any areas where water is allowed to pond next to doors, vents, windows, or other openings. Flooding depths inside buildings in these areas should be limited to $1 \mathrm{ft}$ or less. Buildings with openings below the grade of adjacent roads are also subject to flooding, with flood levels dependent upon the topography in that location. 


\section{INTRODUCTION}

In November 1995, P-SQUARED Technologies, Inc., (P2T) completed an assessment of flood potential for seven buildings at the Y-12 Plant (P2T, 1995). That study investigated the effect of the assumed occurrence of the 10,000-year frequency flood and summarized the expected flood elevations associated with that event in the vicinity of Buildings 9204-2, 9204-2E, 9206, 9212, 9215, 9720-5, and 9995.

In November 1997, P2T was tasked with the following items:

- investigate the flood potential for the same group of seven buildings for the assumed occurrence of the 500-year and the 2000-year frequency floods; and

- investigate the flood potential at Building $9720-38$ for the assumed occurrence of the 500-year, 2000-year, and 10,000-year frequency floods.

A total of eight buildings are the focus for the current study. These buildings are shown on Fig. 1.1.

The methodology used to define flood potential for the 500-year and 2000-year flood frequencies at the seven buildings originally investigated in the 1995 P2T study is identical to the methodology described in the 1995 P2T report. The reader is referred to that report for a more complete discussion of the hydrologic and hydraulic models used and the underlying assumptions and limitations of our approach. This report presents only a brief summary of that approach, along with detailed results of the current effort to define the 500year and 2000-year flood potential.

P2T developed a different analytical approach to define flood potential for Building 9720-38. The approach and subsequent results are described in more detail in Section 3.2.2 of this report. 


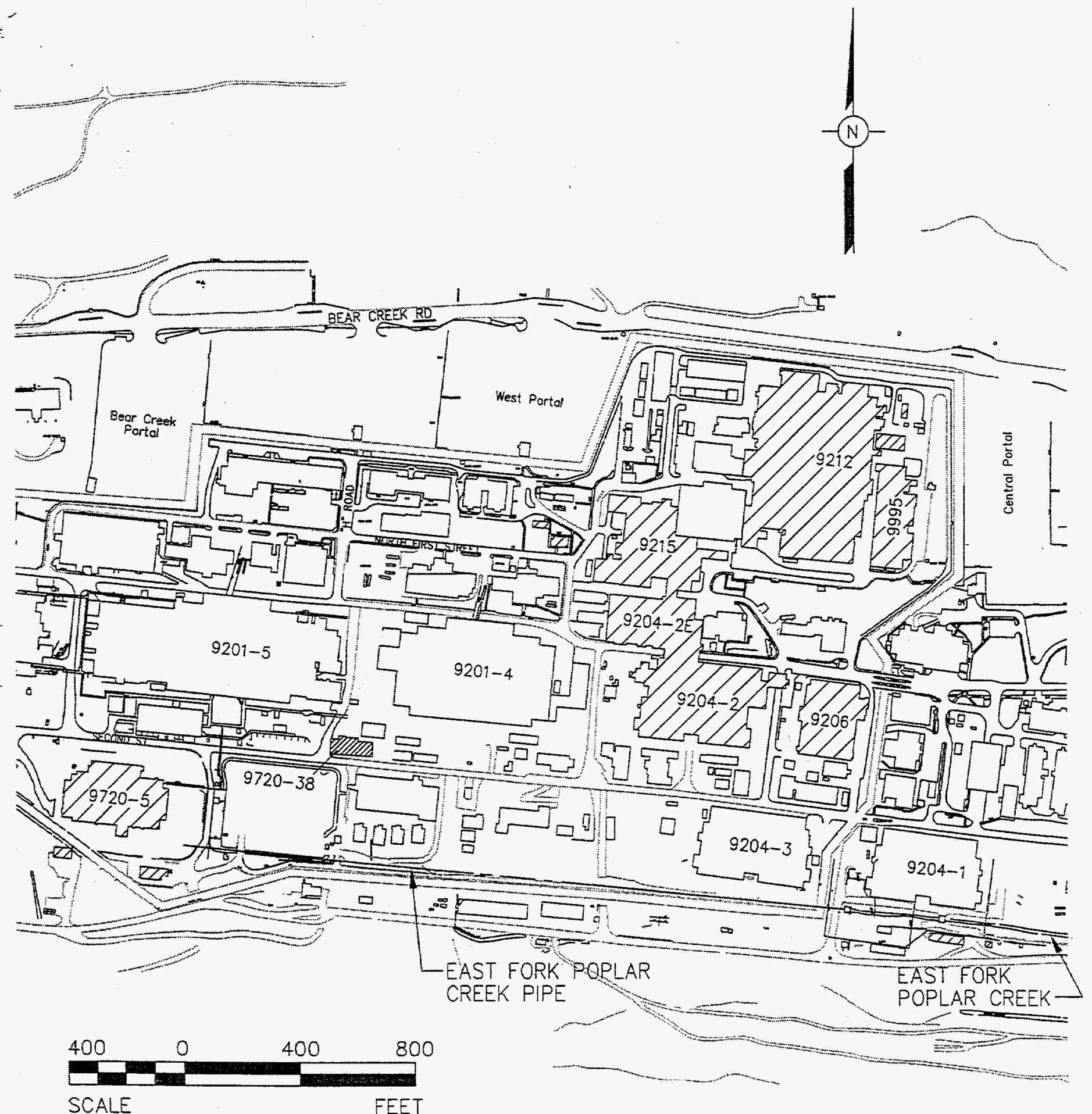

Fig. 1.1. General location map of study area within the Y-12 Plant. 


\section{PREVIOUS WORK AT Y-12 PLANT}

In 1991, the Tennessee Valley Authority (TVA) published a flood report for several Department of Energy (DOE) facilities in Oak Ridge, including the Y-12 Plant (TVA, 1991). The TVA report includes rainfall depth and duration data and an analysis of flood potential for major streams in the Oak Ridge Reservation (ORR). Table 2.1 shows precipitation depth versus duration data from the TVA report.

Table 2.1. Rainfall depth in inches for varying durations and frequencies (from TVA, 1991)

\begin{tabular}{cccc}
\hline Duration & 500 year & 2000 year & 10,000 year \\
\hline 5 minutes & 1.0 & 1.3 & 1.7 \\
10 minutes & 1.7 & 2.4 & 3.2 \\
15 minutes & 2.35 & 3.2 & 4.3 \\
30 minutes & 3.3 & 4.5 & 6.4 \\
1 hour & 4.7 & 6.8 & 9.5 \\
2 hours & 5.7 & 8.5 & 12.4 \\
3 hours & 6.9 & 10.2 & 14.7 \\
6 hours & 8.2 & 12.3 & 18.1 \\
\hline
\end{tabular}

The hydrologic analyses used to determine peak flood elevations at various locations throughout the Y-12 Plant were based on these rainfall relationships.

The TVA report also includes discharge frequency relationships and computed water surface profiles for East Fork Poplar Creek (EFPC). These data were used by P2T in defining the EFPC water surface profile for the 500-year, 2000-year, and 10,000-year frequency floods.

No consideration was given to refining or otherwise revising the rainfall frequency and stream discharge frequency data presented in the TVA report. 


\section{ANALYSES OF EXPECTED FLOODING CONDITIONS}

\subsection{EFPC FLOOD ELEVATIONS}

As described in the 1995 P2T report, EFPC water surface profiles were computed in order to define flood potential at Building 9720-5 and to provide downstream boundary conditions for subsequent UNET modeling of other Y-12 Plant areas. The model used to compute water surface profiles for the 500-year and 2000-year events was the same HEC-2 model developed by P2T in 1995. This model was described in detail in a previous P2T report (P2T, 1995). Flood discharges and starting water surface elevations at the downstream boundary of the P2T model for the respective simulations were based on data presented in the 1991 TVA report.

Figure 3.1 presents the EFPC water surface profiles computed by P2T. The profiles for the 500-year and 2000-year frequencies were computed as part of the current study; the previously computed 10,000 year profile is included for the sake of comparison.

As shown in Fig. 3.1, the computed flood elevations at Building 9720-5 (at the upstream end of the water surface profile model) are 966.9 and 969.9 , respectively, for the 500-year and 2000-year flood events.

\subsection{FLOOD ELEVATIONS WITHIN Y-12 PLANT AREA}

Flood potential for Building 9720-5 was defined using the P2T HEC-2 model discussed in Section 3.1. Flood potential for the remaining six buildings from the original list of seven buildings was defined using the UNET model. Flood potential for Building 9720-38 was defined using the HEC-RAS model. Modeling results from both UNET and HEC-RAS are presented in this section.

The estimates of flood potential described in this section are based on the assumption that the storm rainfall associated with the flood events investigated is of sufficient magnitude to completely saturate pervious surfaces, fill depressional and storage areas (including rooftops), and surcharge the existing stormwater drainage system. In other words, P2T assumed that surface runoff equals rainfall during the highest intensity portion of each storm investigated. To the extent that this approach ignores losses which may occur (such as rooftops which may store large volumes of water), the results presented may be conservative. However, since information on rooftop geometry and drainage systems is not available, and since the intent of this study is to define flood potential, this approach is judged to be valid.

\subsubsection{UNET Simulation Results}

The 1995 P2T report provides a description of the UNET model, discusses drainage basin delineation and generation of flood hydrographs for the design storm, and describes how cross sections were generated for the simulated channels (or reaches) of interest. The UNET model developed as described in that report was used again in the current study to determine flood potential for the 500-year and 2000-year flood events. Discharge hydrographs for these storms were based on the rainfall data presented in Table 2.1. 
$3-2$

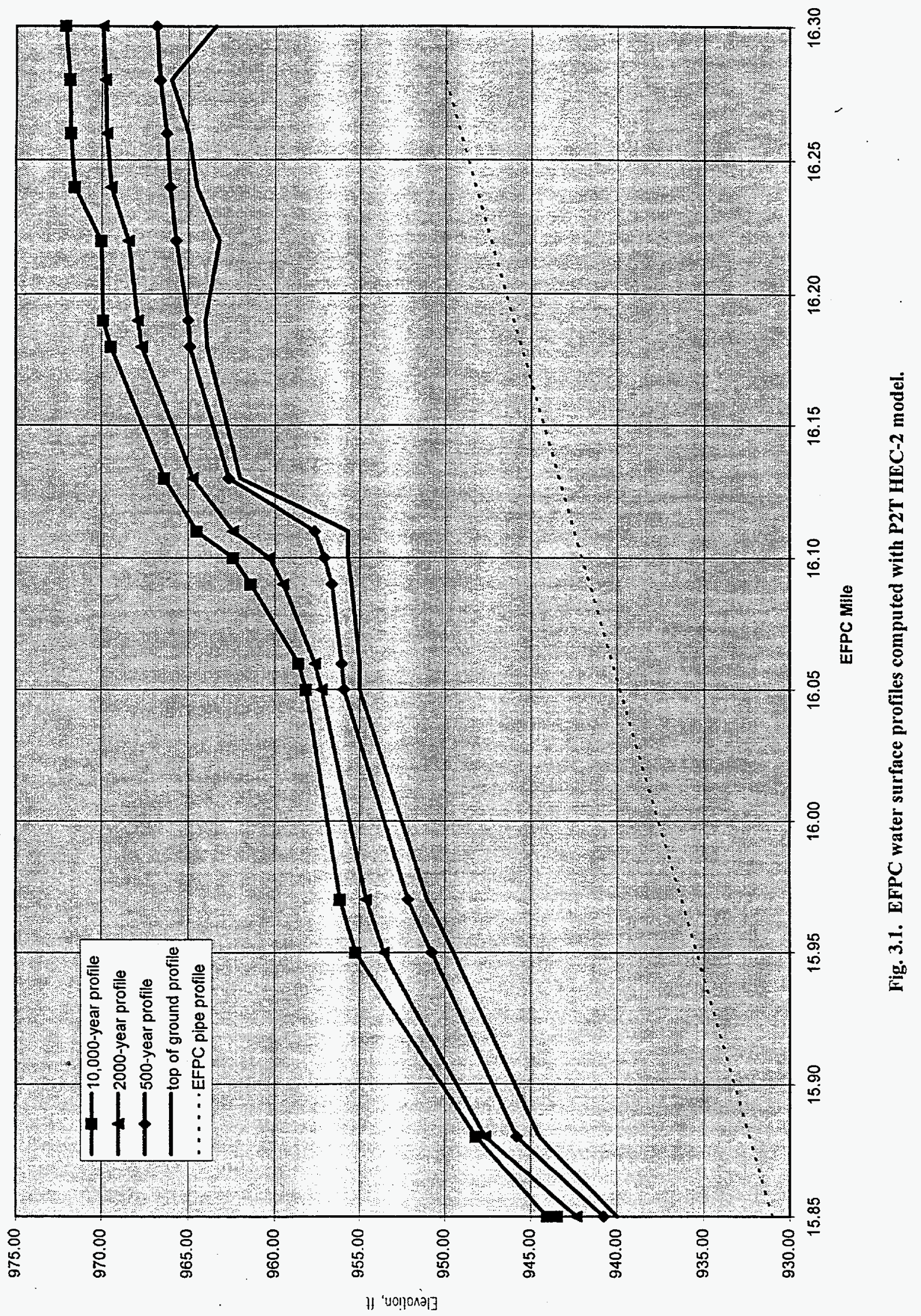


Figure 3.2 shows the location of the UNET reaches used to define flood potential for buildings 9204-2, 9204-2E, 9206, 9212, 9215, and 9995. The downstream boundary conditions for UNET reaches 10 and 13 for the 500-year and 2000-year flood events were based on the results of the P2TEFPC model discussed in Section 3.1. The UNET simulation methodology described in the 1995 P2T report was repeated for the current effort.

Figures 3.3 through 3.9 show the peak water surface profiles computed by UNET for the 500-year and 2000-year flood events for those reaches that lie adjacent to the buildings of interest. These figures include the 10,000-year profiles first presented in the 1995 study for comparison.

\subsubsection{HEC-RAS Simulation Results}

In order to define flood potential at Building 9720-38 for the 500-year, 2000-year, and 10,000-year flood events, P2T used the U.S. Army Corps of Engineers HEC-RAS water surface profile model. HEC-RAS is the first in the Next Generation series of software to be developed by the Corps of Engineers and is intended to replace the HEC-2 model.

Building 9720-38 is subject to flooding by excess surface runoff flowing from west to east, particularly on the northeast side of the building where runoff from a relatively large contributing drainage area will flow through a narrow opening between adjacent buildings. Figure 3-10 shows Building 9720-38, its assumed contributing drainage area in a large storm, and the eight cross sections used to compute water surface profiles for the respective flood events investigated. Peak flood discharges for the respective flood events were computed based on standard hydrologic techniques and the rainfall data presented in Table 2.1.

The HEC-RAS model was used to compute peak water surface profiles in this area rather than the UNET model because of the steep region between cross sections 5 and 6 on the west side of Building 9720-38. This slope is expected to generate supercritical flow conditions (characterized by shallow depths and rapid velocities). While the UNET model is limited to subcritical flow conditions, HEC-RAS was developed to simulate the simultaneous occurrence of both subcritical flow and supercritical flow conditions within a given reach as is expected to occur here.

The water surface profiles computed using the HEC-RAS model for the three flood events investigated are shown in Fig. 3.11. The flood elevations at the downstream boundary of the modeled reach (at cross section 1) for each of the three flood frequencies were assumed based on the topography at this location. Additional analyses performed with the HEC-RAS model indicated that the computed flood elevations at the northeast corner of Building 9720-38, where flood potential is maximized, are not sensitive to the assumed downstream water surface elevation. 


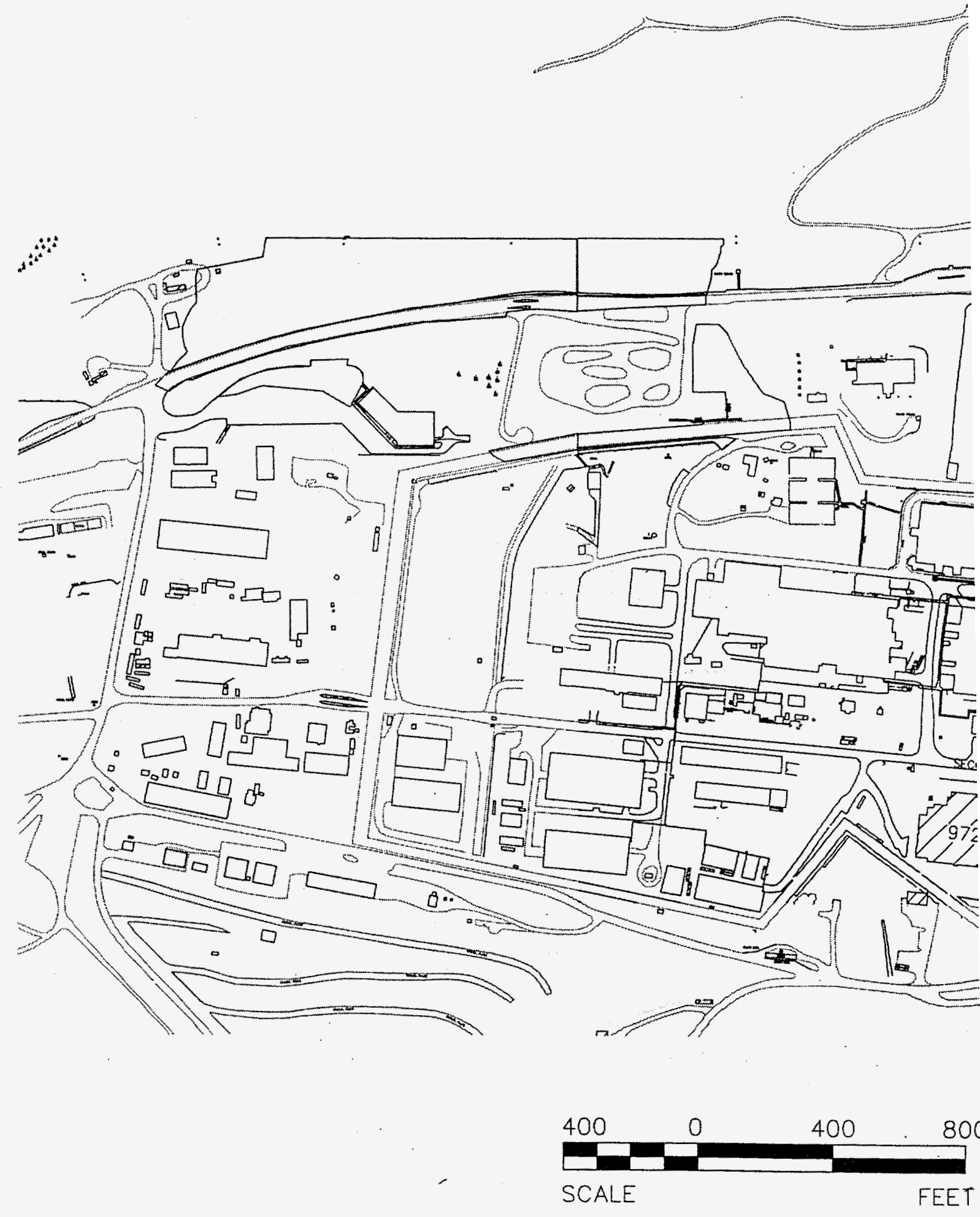

Fig. 3.2. Location of UNET reaches 1 through 13. 


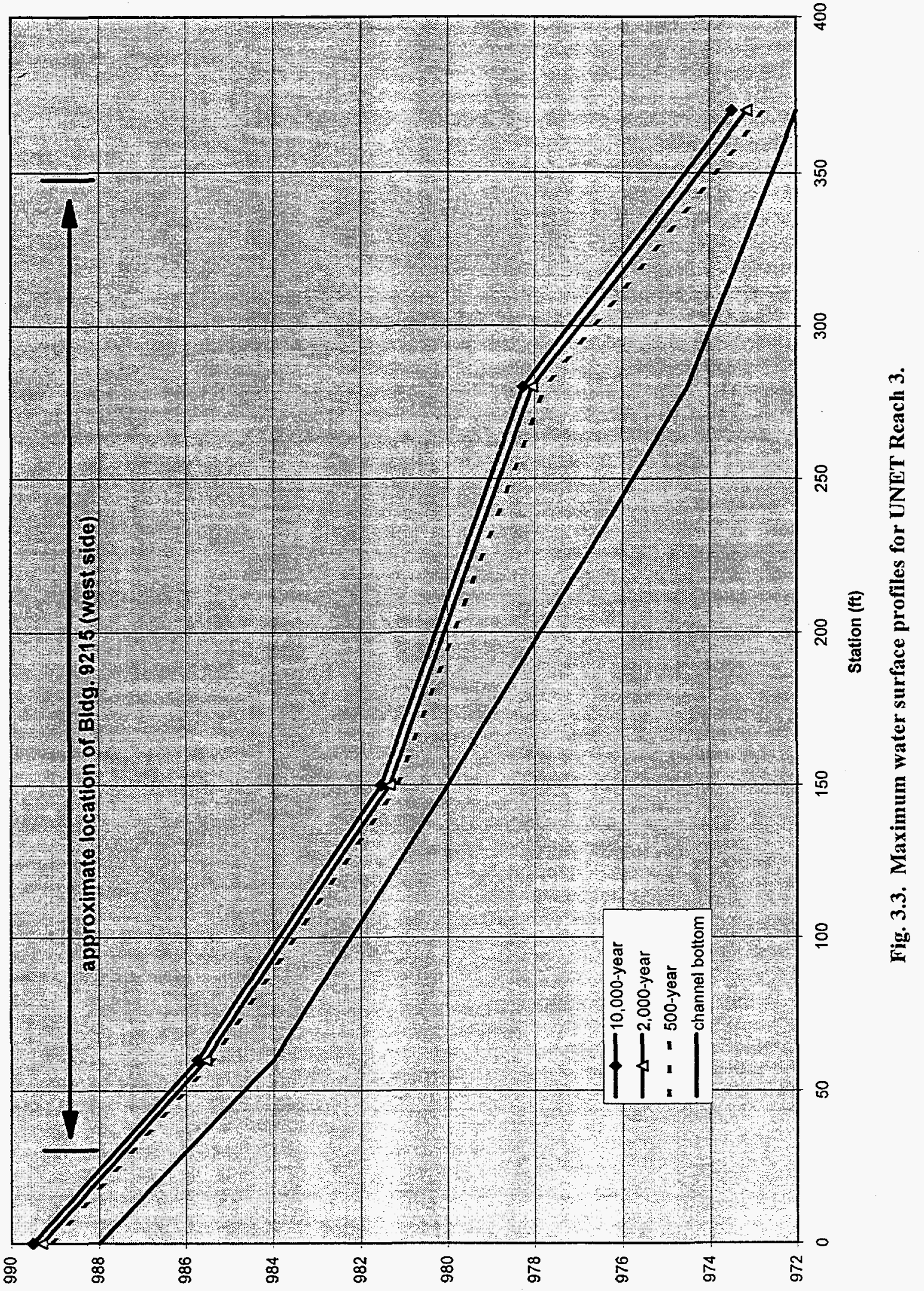

(H) น0!p시 




Fig. 3.4. Maximum water surface profiles for UNET Reach 5. 


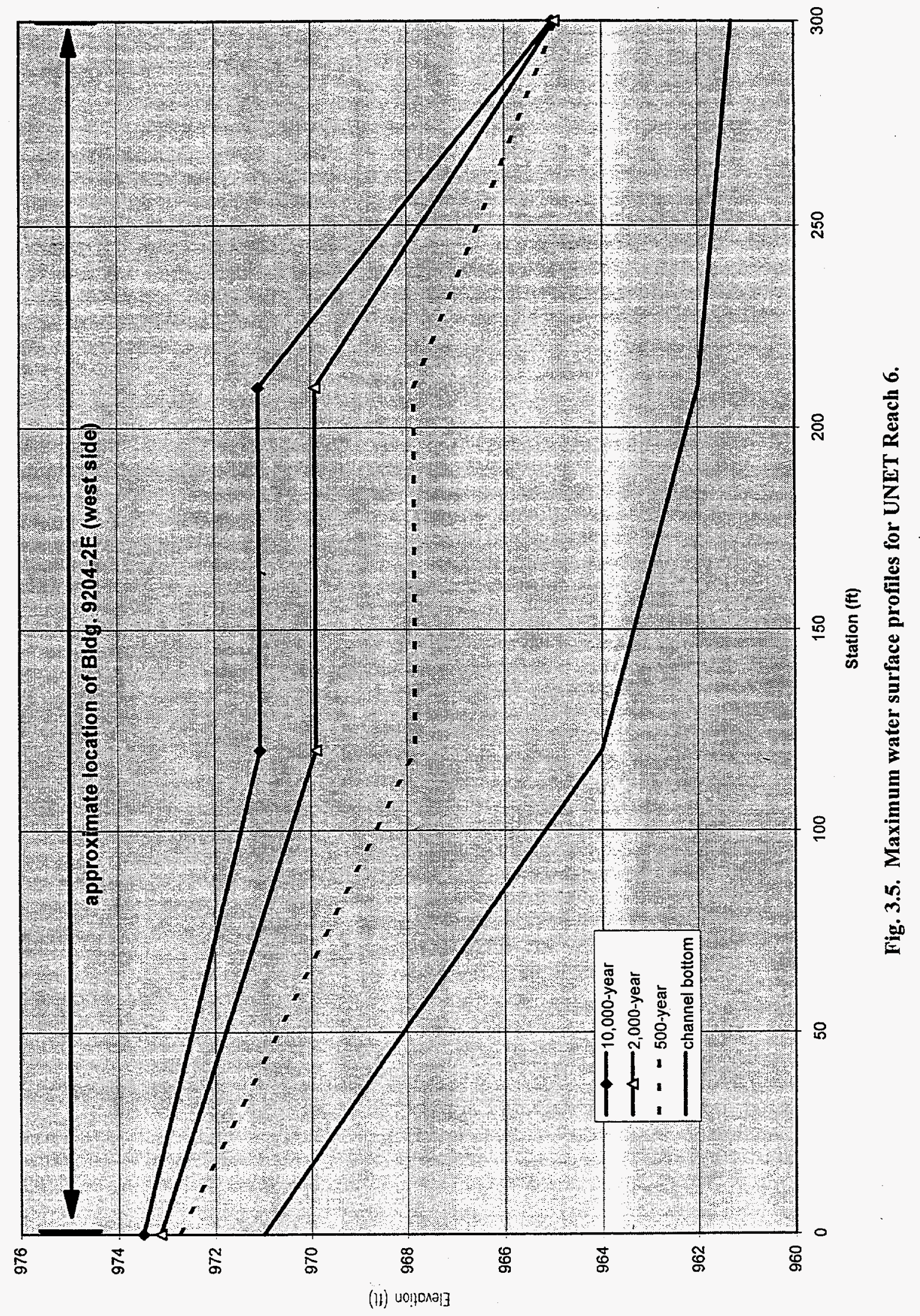




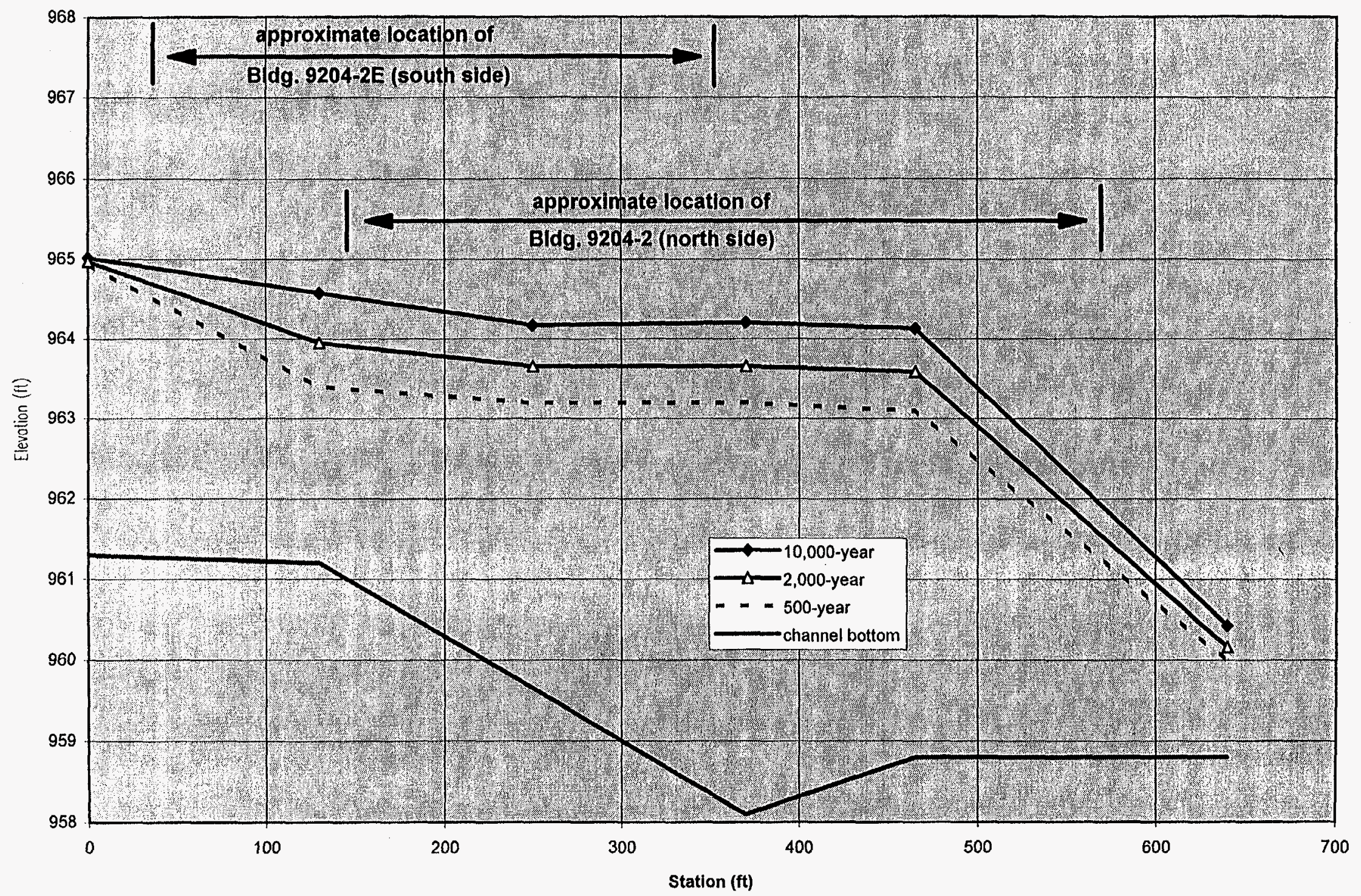

Fig. 3.6. Maximum water surface profiles for UNET Reach 9. 


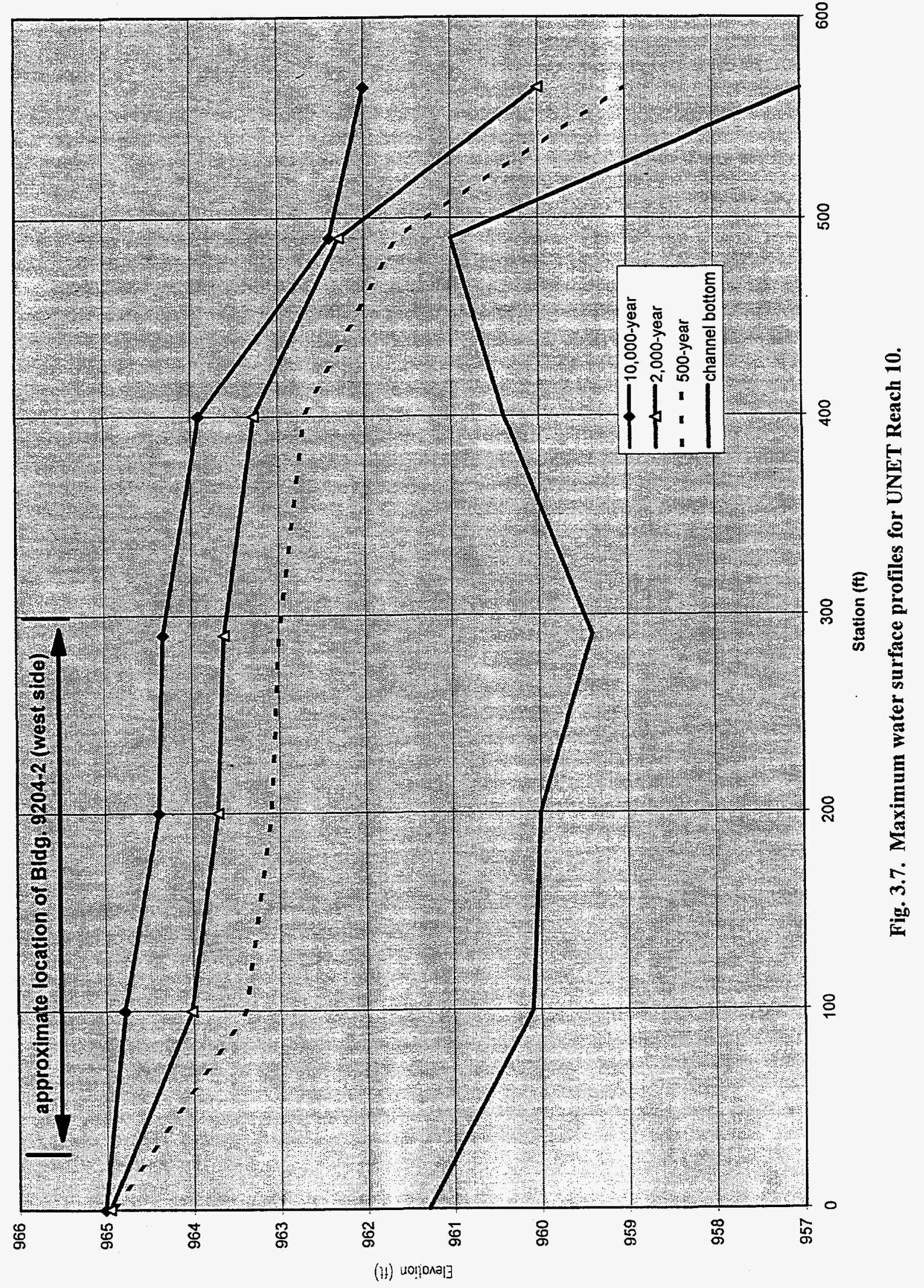




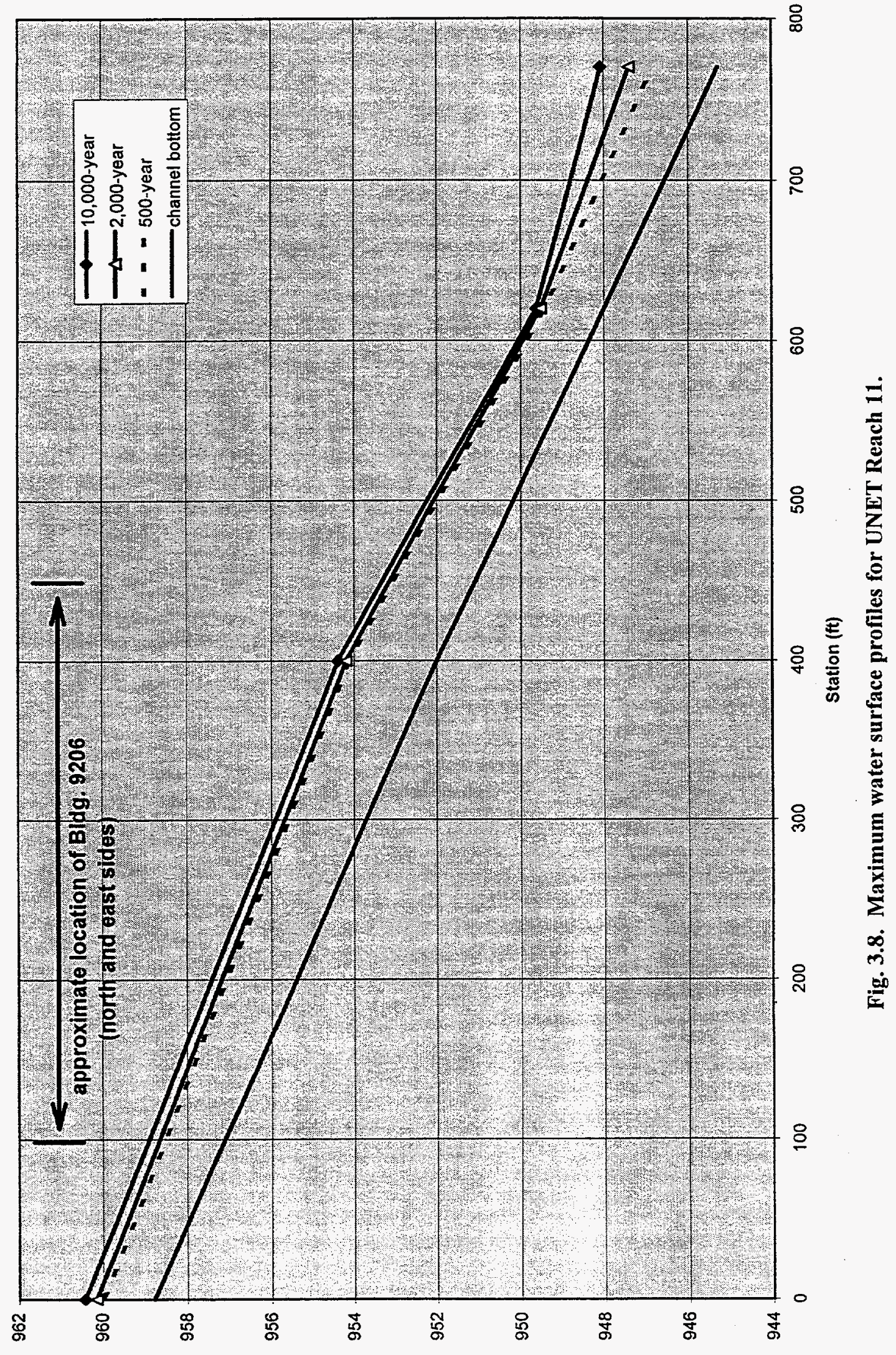

(1I) บ윰저] 


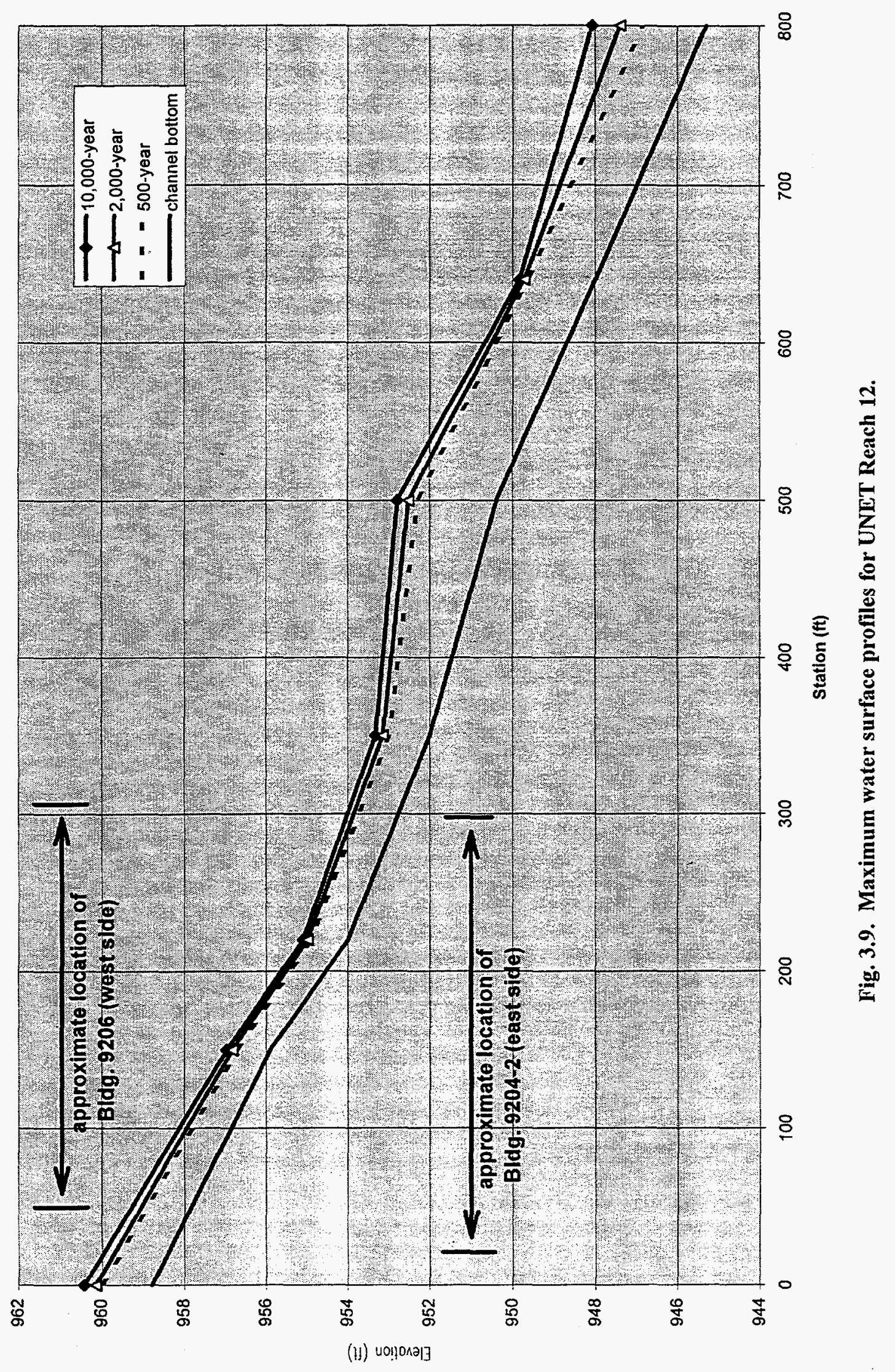




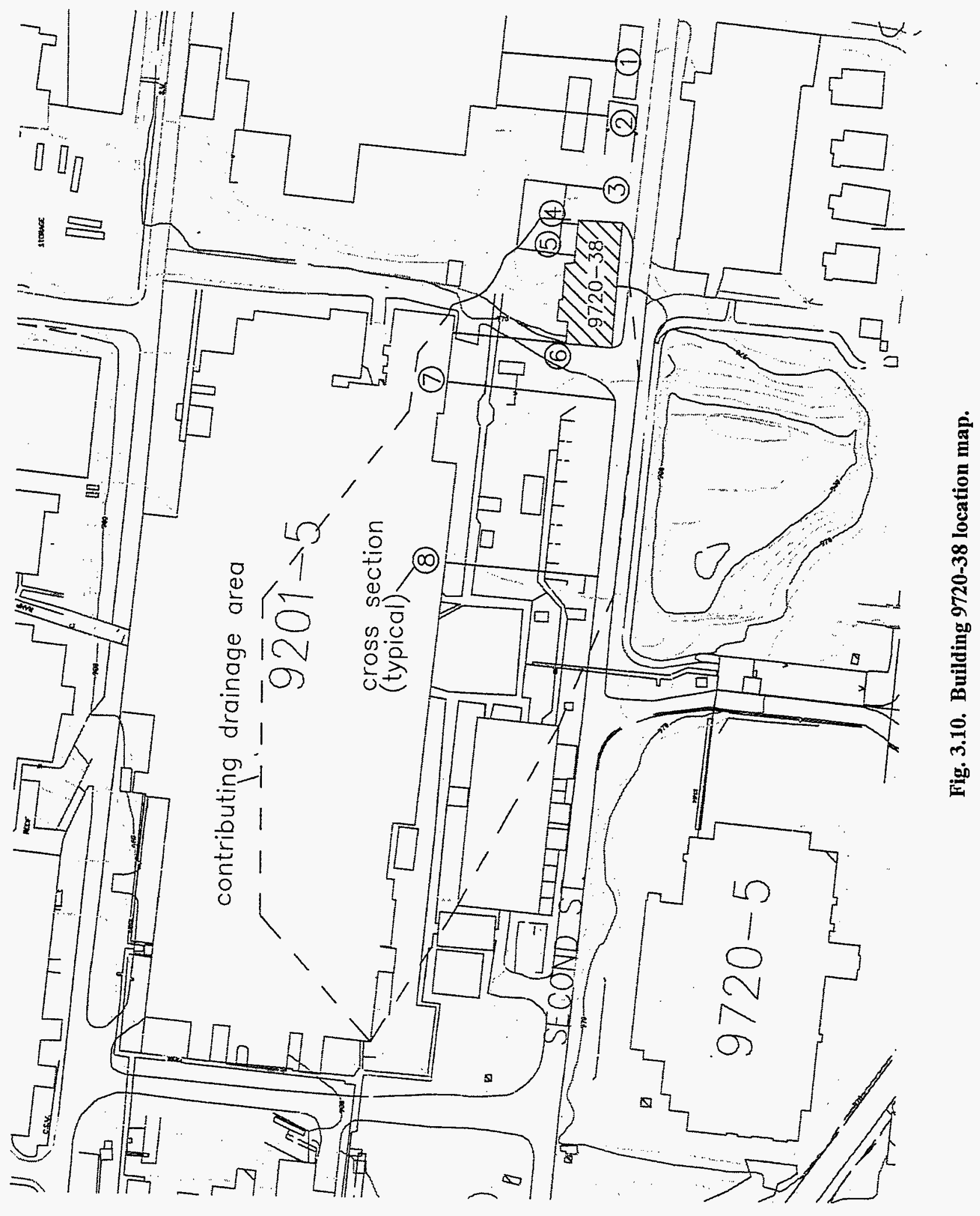









\section{SUMMARY OF FLOOD POTENTIAL}

Because of the magnitude of the rainfall associated with the 500-year and 2000-year floods, all of the eight buildings investigated in this study are potentially subject to minor flooding from rooftop runoff. P2T has assumed that runoff will be discharged along the entire perimeter of each rooftop. Water may enter buildings at any location where this runoff is not immediately drained away, particularly at low points such as loading docks or pits. The pit area at the northwest corner of Building 9202 is an example of a potential flooding location. The depth of flooding inside any given building from excessive rooftop runoff will vary depending upon the characteristics and geometry of the rooftop and the size of the low area to which water will drain. A precise determination of the depth of flooding at these locations is beyond the scope of this effort, but will typically be less than $1 \mathrm{ft}$.

Another general source of flooding potential exists where buildings with finished floor elevations that are below road grade are adjacent to roads carrying surface runoff. The northern boundary of Building 9215 is subject to flooding of this nature, as some of the runoff being conveyed in the road on that side of the building (UNET Reach 2) will drain toward the low point adjacent to Building 9215 . Flooding depth in these locations could easily reach the adjacent road grade elevation, as large runoff volumes are temporarily stored in these low areas.

In general, any building within the Plant where flood protection is afforded by a catch basin situated in a low point adjacent to that building is subject to flooding, because the intensity of runoff associated with the storm events investigated will cause the stormwater system to be surcharged. Any buildings with internal floor drains connected to the stormwater system are subject to flooding for the same reason.

A brief discussion of flood potential for each of the buildings investigated follows.

\section{Building 9204-2}

Building 9204-2 is subject to flooding primarily from flood runoff draining through adjacent streets. The maximum flooding depths associated with the flood events investigated were determined from UNET model simulations. Computed peak flooding depths on the north side of the building range from about 2.4 to $5.1 \mathrm{ft}$ in the 500-year storm and from about 2.8 to $5.5 \mathrm{ft}$ in the 2000-year storm (see Fig. 3.6). Computed peak flooding depths on the west side of the building range from about 3.1 to $3.6 \mathrm{ft}$ in the 500-year storm and from about 3.7 to $4.3 \mathrm{ft}$ in the 2000-year storm (see Fig. 3.7). Computed peak flooding depths on the east side of the building range from about 0.8 to $1.1 \mathrm{ft}$ in the 500 -year storm and from about 0.9 to $1.3 \mathrm{ft}$ in the 2000 -year storm (see Fig. 3.9).

\section{Building 9204-2E}

Building 9204-2E is subject to flooding primarily from flood runoff draining through adjacent streets. The maximum flooding depths associated with the flood events investigated were determined from UNET model simulations. Computed peak flooding depths on the north side of the building range from about 1.7 to $6.2 \mathrm{ft}$ in the 500 -year storm and from about 1.8 to $6.3 \mathrm{ft}$ in the 2000 -year storm (see Fig. 3.4). Computed peak flooding depths on the west side of the building range from about 1.8 to $5.8 \mathrm{ft}$ in the 500-year storm and from about 2.3 to $7.8 \mathrm{ft}$ in the 2000-year storm (see Fig. 3.5). On the east side of the building, flooding 
potential is maximized at the northeast corner of the building, where water will pond to a depth of about $1.7 \mathrm{ft}$ in the 500 -year storm and about $1.8 \mathrm{ft}$ in the 2000-year storm (see Fig. 3.4). Computed peak flooding depths on the south side of the building range from about 0.8 to $1.1 \mathrm{ft}$ in the 500 -year storm and from about 0.9 to $1.3 \mathrm{ft}$ in the 2000 -year storm (see Fig. 3.6).

\section{Building 9206}

Building 9206 is subject to flooding primarily from flood runoff draining through adjacent streets. The maximum flooding depths associated with the flood events investigated were determined from UNET model simulations. Computed peak flooding depths on the north side of the building range from about 1.4 to $1.8 \mathrm{ft}$ in the 500 -year storm and from about 1.5 to $1.9 \mathrm{ft}$ in the 2000-year storm (see Fig. 3.8). Computed peak flooding depths on the east side of the building range from about 1.8 to $2.0 \mathrm{ft}$ in the 500-year storm and from about 1.9 to $2.1 \mathrm{ft}$ in the 2000-year storm (see Fig. 3.8). Computed peak flooding depths on the west side of the building range from about 0.9 to $1.0 \mathrm{ft}$ in the 500 -year storm and from about 1.1 to $1.2 \mathrm{ft}$ in the 2000-year storm (see Fig. 3.9). On the south side of the building, water will pond to a maximum depth of less than $2 \mathrm{ft}$ in the area between Buildings 9206 and 9744 .

\section{Building 9212}

Flooding potential for Building 9212 will be limited to rooftop runoff temporarily ponding in low areas adjacent to the building, such as at the northwest corner of the building. Flooding depths inside the building at these locations will generally be less than $1 \mathrm{ft}$.

\section{Building 9215}

Building 9215 is subject to flooding primarily from flood runoff draining through adjacent streets. The maximum flooding depths associated with the flood events investigated were determined from UNET model simulations. Computed peak flooding depths on the west side of the building range from about 1.1 to $3.3 \mathrm{ft}$ in the 500-year storm and from about 1.3 to $3.5 \mathrm{ft}$ in the 2000-year storm (see Fig. 3.3). Computed peak flooding depths on the south side of the building range from about 1.9 to $6.2 \mathrm{ft}$ in the 500 -year storm and from about 2.2 to $6.3 \mathrm{ft}$ in the 2000 -year storm (see Fig. 3.4).

\section{Building 9720-5}

Building $9720-5$ is subject to flooding primarily from EFPC backwater. The maximum flooding depths associated with the flood events investigated were determined from HEC-2 model simulations. The computed peak flood elevation from EFPC backwater in the 500year flood is 966.9 , and in the 2000 -year flood is 969.9 , which will cause average ponding depths of about $1 \mathrm{ft}$ and $4 \mathrm{ft}$, respectively, above the parking lot around the building.

\section{Building 9720-38}

Building $9720-38$ is subject to flooding primarily from flood runoff draining from west to east; maximum flood depths would occur along the north side of the building. The maximum flooding depths associated with the flood events investigated were determined from HEC-RAS model simulations. Computed peak flooding depths along the north side 
of the building range from 0.8 to $1.2 \mathrm{ft}$ in the 500 -year flood, 0.9 to $1.3 \mathrm{ft}$ in the 2000-year flood, and 1.1 to $1.4 \mathrm{ft}$ in the 10,000-year flood (see Fig. 3.11).

\section{Building 9995}

Flooding potential for Building 9995 will be limited to rooftop runoff temporarily ponding in low areas adjacent to the building. Flooding depths inside the building at these locations will generally be less than $1 \mathrm{ft}$. 


\section{REFERENCES}

P-SQUARED Technologies, Inc. (P2T), 1995. Assessment of Flood Potential for Seven Buildings at the Y-12 Plant. Report submitted to Lockheed Martin Energy Systems, Inc., Oak Ridge, Tennessee. DOE Contract No. DE-AC05-840R21400.

Tennessee Valley Authority (TVA), 1991. Flood Analyses for Department of Energy Y-12, ORNL, and K-25 Plants. Report submitted to Martin Marietta Energy Systems, Inc., Oak Ridge, Tennessee. TVA Contract No. TV-837730V.

U.S. Department of Energy (DOE), 1994. DOE Standard: Natural Phenomena Hazards Design and Evaluation Criteria for Department of Energy Facilities, DOE-STD-102094, Washington, D.C. 